\title{
Correction to: Polymorphisms within the Telomerase Reverse Transcriptase gene (TERT) in four breeds of dogs selected for difference in lifespan and cancer susceptibility
}

Camille A. McAloney ${ }^{1,2}$, Kevin A. T. Silverstein ${ }^{3}$, Jaime F. Modiano ${ }^{3,4}$ and Anindya Bagchi, ${ }^{3,5^{*}}$

Correction to: BMC Vet Res 10, 20 (2014)

https://doi.org/10.1186/1746-6148-10-20

The original article [1] contains an acknowledgement to Mary "Andy" Scott for graphics assistance.

The authors would like to note that this person's name has since legally changed to Andrew Ezekiel Scott, and that the acknowledgement to Mr. Scott should now reflect their new name.

\footnotetext{
Author details

${ }^{1}$ Augsburg College, Minneapolis, MN 55454, USA. ${ }^{2}$ College of Veterinary Medicine, University of Minnesota, St. Paul, MN 55108, USA. ${ }^{3}$ Masonic Cancer Center, University of Minnesota, Minneapolis, MN 55455, USA. ${ }^{4}$ Department of Veterinary Clinical Sciences, College of Veterinary Medicine, University of Minnesota, St. Paul, MN 55108, USA. ${ }^{5}$ Department of Genetics, Cell Biology and Development, School of Medicine, 420 Delaware St. SE, MMC 806, Minneapolis, MN 55455, USA.
}

Published online: 06 September 2021

\section{Reference}

1. McAloney CA, et al. Polymorphisms within the Telomerase Reverse Transcriptase gene (TERT) in four breeds of dogs selected for difference in lifespan and cancer susceptibility. BMC Vet Res. 2014;10:20 https://doi.org/1 0.1186/1746-6148-10-20.

The original article can be found online at https://doi.org/10.1186/1746-614810-20.

* Correspondence: bach005@umn.edu

${ }^{3}$ Masonic Cancer Center, University of Minnesota, Minneapolis, MN 55455, USA

${ }^{5}$ Department of Genetics, Cell Biology and Development, School of Medicine, 420 Delaware St. SE, MMC 806, Minneapolis, MN 55455, USA

Full list of author information is available at the end of the article

(c) The Author(s). 2021 Open Access This article is licensed under a Creative Commons Attribution 4.0 International License, which permits use, sharing, adaptation, distribution and reproduction in any medium or format, as long as you give appropriate credit to the original author(s) and the source, provide a link to the Creative Commons licence, and indicate if changes were made. The images or other third party material in this article are included in the article's Creative Commons licence, unless indicated otherwise in a credit line to the material. If material is not included in the article's Creative Commons licence and your intended use is not permitted by statutory regulation or exceeds the permitted use, you will need to obtain permission directly from the copyright holder. To view a copy of this licence, visit http://creativecommons.org/licenses/by/4.0/. The Creative Commons Public Domain Dedication waiver (http://creativecommons.org/publicdomain/zero/1.0/) applies to the data made available in this article, unless otherwise stated in a credit line to the data. 